\title{
A Lei de Improbidade Administrativa: sua aplicação e apontamentos para uma melhor eficácia
}

\section{The law of administrative misconduct: application and notes for greater efficiency}

\author{
José Carlos de Oliveira* \\ Alex Facciolo Pires ${ }^{*^{*}}$
}

\section{Resumo}

A Constituinte de 1988, buscando reprimir a corrupção, previu a figura da improbidade administrativa no art. 37 , parágrafo $4^{\circ}$. Foi editada, então, a Lei $n^{\circ}$ 8.429/92, Lei de Improbidade Administrativa. A má-fé, a desonestidade, a perversidade e a maldade, aliadas à ilegalidade, são premissas da improbidade administrativa. A Lei é aplicável a todos os agentes públicos, indistintamente, sem qualquer exceção, notadamente aos agentes políticos. Às ações por atos de improbidade administrativa não se aplica a prerrogativa de foro. A sanção consistente na perda da função pública produz o rompimento do laço entre o agente ímprobo e o Estado, porquanto o agente público exibe inidoneidade moral e desvio ético para o exercício de qualquer função pública. A eficácia da Lei de Improbidade Administrativa, apesar dos notáveis e expressivos avanços, ainda é diminuta frente aos desmandos de corrupção de que temos notícia pela imprensa, diariamente, proporcionando uma verdadeira impunidade.

Palavras-chave: Improbidade administrativa. Agente político. Prerrogativa de foro. Perda da função pública. Transação nos atos de improbidade administrativa.

Mestre e Doutor em Direito. Professor do Programa de Pós-Graduação da Universidade Estadual Paulista - UNESP/Franca. Professor de Direito na FCHS/Franca, e-mail: oliveira@franca.unesp. br.

** Mestre em Direito pela Universidade Estadual Paulista - UNESP/Franca. Promotor de Justiça do Ministério Público do Estado de São Paulo, e-mail: piresfalex@gmail.com 


\section{Abstract}

The Constituent Assembly of 1988, seeking to prosecute corruption predicted figure of administrative misconduct in the art. 37, paragraph 4. It was edited, then the law n. 8.429/92. Misconduct Administrative Law. Bad faith, dishonesty, wickedness and evil, combined with illegality, are premises of administrative misconduct. The Misconduct Act applies to all public officials, without distinction, without exception, especially the politicians. Actions for acts of misconduct does not apply to administrative prerogative of the forum. The penalty consisting in the loss of civil service produces the breaking of the bond between the agent and the unrighteous rule, because the public official has exhibited moral deviation and moral unfitness to exercise any public function. Necessary legislative changes to mitigate seal the deal in the acts of administrative impropriety. The effectiveness of the law of administrative misconduct, despite the remarkable and significant progress is still tiny compared to the excesses of corruption that we hear in the press daily, providing even, in fact, a true impunity.

Keywords: Administrative misconduct. Political agent. Prerogative do forum. Public loss of function. Transaction in acts of administrative dishonesty.

\section{Introdução}

O artigo 37 da Constituição Federal de 1988 tratou das disposições gerais sobre a administração pública, prevendo no parágrafo $4^{\circ}$ os atos de improbidade administrativa e suas sanções, buscando reprimir a corrupção. A Lei Federal no 8.429/92, de 02 de junho de 1992, foi o diploma legal que disciplinou e regulamentou a matéria. É na aludida lei que se tipificam os atos de improbidade administrativa e as espécies de cominações: sanção política, cível e administrativa.

A sanção política consiste na suspensão dos direitos políticos do agente ímprobo. A sanção político-administrativa consiste na perda da função pública, na proibição de contratar com o poder público ou dele receber benefícios fiscais ou creditícios, e, por fim, a sanção civil consiste na multa cível, no ressarcimento integral do dano e na perda dos bens ou valores acrescidos ilicitamente ao patrimônio. 
Platão (1994) já salientava que a punição e o afastamento da vida pública dos agentes corruptos pretendem fixar uma regra proibitiva para que os servidores públicos não se deixem induzir por preço nenhum a agir em detrimento dos interesses do Estado.

A fim de evitar o perigo de uma administração corrupta, caracterizada pelo descrédito e ineficiência, o legislador editou a Lei $\mathrm{n}^{\circ}$ 8.429/92, com o intuito de prevenir a corrosão da máquina burocrática do Estado (MORAES, 2010).

No dizer de Martins Júnior (2009), a Lei n 8.429/92 instituiu no Direito brasileiro um autêntico código da moralidade administrativa. No ensinamento de Osório (2007, p. 183), em seu livro Teoria da Improbidade Administrativa, prefaciado pelo catedrático emérito de Direito Administrativo, Eduardo García de Enterría, a Lei Federal $n^{\circ}$ 8.429/92 é, na verdade, uma Lei Geral de Improbidade Administrativa (LGIA) e um Código Geral de Conduta, com normativa jurídica, força coercitiva cogente, alcance nacional e balizador de todo o setor público em suas vertentes fundamentais. Conforme preconiza Osório (2007, p. 21):

São louváveis e necessários os avanços constatados na controlabilidade jurisdicional dos atos administrativos e ampliação das responsabilidades dos gestores públicos, no sistema jurídico brasileiro, diante da fragilização das imunidades do Poder. Eduardo García Enterría, nesse sentido, formulou clássico trabalho sobre o descabimento das imunidades do poder político, trabalho que veio a ser a base de uma série de transformações no direito administrativo espanhol, europeu e latino-americano, considerando um raio de influência direta daquele jurista. A luta contra as imunidades dos Poderes tem sido um dos temas centrais do constitucionalismo contemporâneo e da estruturação das instituições democráticas, onde se situam os sistemas administrativos e jurisdicionais que aplicam normas de direito administrativo.

Com efeito, a Lei de Improbidade Administrativa cataloga três grandes modelos de tipos sancionadores: a) condutas de enriquecimento 
ilícito (art. 9); b) condutas de lesão ao erário (art. 10); e c) condutas de lesão aos princípios que regem a gestão pública (art. 11).

A lei $n^{\circ} 8.429 / 92$ exigiu o dolo nas três espécies de ato de improbidade administrativa (artigos 9, 10 e 11) e permitiu, em uma única espécie (art. 10), a responsabilidade a título de culpa.

Este trabalho visa evidenciar em letras fortes que a improbidade administrativa não é mera ilegalidade do servidor público, mas está qualificada pela má-fé, desonestidade, perversidade e maldade.

Ademais, a Lei de Improbidade Administrativa, por ter conteúdo constitucional, e sob pena de ferir o princípio constitucional da isonomia, deve ser aplicada também aos agentes políticos, porquanto o regime jurídico do impeachment previsto a eles não é incompatível com o regime jurídico constitucional da Lei, que prevê não somente a pena do cargo e a inabilitação do exercício de função pública por prazo determinado, mas também o ressarcimento do dano ao erário, perda dos bens ou valores auferidos ilicitamente, proibição de contratar com o poder público e dele receber benefícios fiscais ou creditícios, e multa cível.

Destarte, a Lei de Improbidade Administrativa não foi feita somente para os agentes públicos comuns. Não há qualquer exceção aos agentes políticos, consoante descrição clara e expressa no texto do artigo $2^{\circ}$ da Lei $n^{\circ} 8.429 / 92$.

Analisamos a questão da prerrogativa de foro nas ações civis por improbidade administrativa. Será que o foro privilegiado de algumas autoridades na seara criminal se aplicaria nessas ações?

Noutro giro, refletimos também acerca da importância de uma alteração legislativa para mitigar a vedação de transação nos atos de improbidade administrativa. Com a possibilidade de composição ou acordo do legitimado com o agente ímprobo, penalidades rápidas serão impostas ao agente corrupto, e a sociedade terá uma resposta imediata diante da prática da corrupção. Assim, a sensação de impunidade diminuiria, sem abrir mão, em qualquer hipótese, do ressarcimento integral do dano ao erário público causado. 
Refletimos também acerca da necessidade de se entender que, na sanção consistente da perda da função pública prevista na Lei $n^{\circ}$ 8.429/92, existe o rompimento integral do laço entre o agente ímprobo e o Estado, porquanto o agente público, quando da prática do ato ímprobo, exibe inidoneidade moral e desvio ético para o exercício de qualquer função pública.

E, finalmente, analisamos a eficácia do diploma legal em comento. Será que ele está sendo utilizado de maneira satisfatória e eficaz pelos legitimados à propositura de ações civis públicas por ato de improbidade administrativa? Reflitamos.

\section{Oue é ou não improbidade administrativa}

O vocábulo latino improbitate tem o significado de "desonestidade", e a expressão improbus administrator quer dizer "administrador desonesto ou de má-fé" (PAZZAGLINI, 2009). Na lição de Caetano (1970, p. 684), ao abordar o dever de probidade, "o funcionário deve servir à Administração com honestidade, procedendo no exercício de suas funções sempre no intuito de realizar os interesses públicos, sem aproveitar os poderes ou facilidades delas decorrentes em proveito pessoal ou de outrem a quem queira favorecer". Segundo Osório (2007, p. 39), o importante é situar a improbidade administrativa num marco ético-institucional, como uma espécie de má gestão pública:

A dificuldade reside em situar corretamente a improbidade no campo axiológico da má gestão pública, ou seja, como uma categoria ético-normativa apta a designar precisamente fenômenos situáveis no âmbito da má gestão pública. Realmente, a novidade consiste em posicionar a improbidade no universo rico e complexo da má gestão pública, deixando claro que se trata de conceitos próximos, porém distintos, na medida em que nem toda má gestão pública será expressão da improbidade, ainda que o inverso seja verdadeiro.

O referido autor conclui que a improbidade administrativa não é um mero ato em desconformidade com letra fria da lei: 
O fenômeno que designamos como improbidade administrativa, no direito administrativo brasileiro, desenhado no artigo 37 , paragrafo $4^{\circ}$ da $C F$, no marco da Lei n. 8.429/92, define-se como a má gestáo pública gravemente desonesta ou gravemente ineficiente, por ações ou omissões, dolosas ou culposas, de agentes públicos no exercício de suas funções ou em razão delas, com ou sem participação dos particulares, observados os pressupostos gerais de configuração típica e de imputação. A improbidade é espécie do gênero má gestáo pública. $A$ corrupção é espécie do gênero improbidade. A compreensão desses fenômenos a partir dessas relações é fundamental para perceber suas características e peculariedades. A abordagem com o foco na ineficiência, quando sinalizada com nota de gravidade, também pode aproximar-se da própria corrupção, na medida em que ambas traduzem níveis distintos de má gestão pública e ambas constituem espécie de improbidade administativa. O próprio histórico da improbidade administrativa com elementos dos crimes de responsabilidade denuncia sua funcionalidade repressiva em relação a atos culposos. Daí por que resulta admissível, constitucionalmente, a improbidade culposa, dando-se densidade ao princípio da eficiência. (OSÓRIO, 2007, p. 464)

Neste aspecto, o Superior Tribunal de Justiça enfatizou:

É cediço que a má-fé é premissa do ato ilegal e ímprobo. Consectariamente, a ilegalidade só adquire o status de improbidade quando a conduta antijurídica fere os princípios constitucionais da Administração Pública coadjuvados pela má-fé do administrador. A improbidade administrativa, mais que um ato ilegal, deve traduzir, necessariamente, a falta de boa-fé, a desonestidade, o que não restou comprovado nos autos pelas informações disponíveis no acórdão recorrido, calcadas, inclusive, nas conclusões da Comissão de Inquérito (Recurso Especial n. 480.387/SP - $1^{\text {a }}$ Turma Rel. Min. Luiz Fux - DJU 16-3-2004). (PAZZAGLINI FILHO, 2009, p. 4, nota 11) 
Nesse mesmo sentido vem decidindo o Tribunal de Justiça de São Paulo:

Improbidade é maldade, perversidade, corrupção, devassidão, desonestidade, falsidade, qualidade de quem atenta contra os princípios ou as regras da lei, da moral e dos bons costumes, com propósitos maldosos ou desonestos. Ausente essas características na inobservância formal do ordenamento, não há como aplicar pena por improbidade ao agente público (Apelação n. 400.147-5/5 - Auriflama, Rel. Des. Renato Nalini, DJ 15-8-2006). (PAZZAGLINI FILHO, 2009, p. 4, nota 12)

Refletindo acerca do contexto apresentado, podemos revelar que foi com brilhantismo que lecionou Pazzaglini Filho (2009) ao revelar que improbidade administrativa não é uma atuação do agente simplesmente em desconformidade com a letra fria da lei; não pode ser considerada como sinônimo de mera ilegalidade administrativa, mas como uma ilegalidade qualificada pela imoralidade, desonestidade e má-fé.

Não nos parece crível punir o agente público quando atua de forma inábil ou imperfeita estando ausente o elemento de desonestidade e fraude (FIGUEIREDO, 2004). Nesse sentido:

ApCív 1.0024.94.077404-5/001, 5 Câm. Cív., rel. Des. Maria Elza. Improbidade administrativa. Caracterização. Recurso provido. Segundo o Min. Luiz Fux, do STJ, a lei de improbidade administrativa, que explicitou o cânone do artigo 37 , parágrafo $4^{\circ}$, da $C F$, teve como escopo impor sanções aos agentes públicos incursos em atos de improbidade nos casos em que: a) importem em enriquecimento ilícito (artigo $9^{\circ}$ ); b) que causam prejuízo ao erário público (artigo 10); c) que atentem contra os princípios da Administração Pública (artigo 11), aqui também compreendida a lesão à moralidade administrativa". Destarte, para que ocorra o ato de improbidade administrativa disciplinado pela referida norma, é mister o alcance de um dos bens jurídicos acima referidos e tutelados pela norma especial. O recebimento indevido de dupla remuneração para o exercício de uma mesma função, bem como seu irregular pagamento, 
evidencia má-fé objetiva dos apelados. É cediço que a máfé é premissa do ato ilegal é ímprobo. Consectariamente, a ilegalidade só adquire o status de improbidade quando a conduta antijurídica fere os princípios constitucionais da Administração Pública coadjuvados pela má-fé do administrador. A improbidade administrativa, mais que um ato ilegal, deve traduzir, necessariamente, a falta de boafé, a desonestidade (TJMG, 46.02.2006). (Resp 480.387SP, rel. Min. Luiz Fux). Julg. 16 marc. 2004. Publ. DJ 24.05.2004, p. 163)

\section{Aplicação da lei de improbidade aos agentes políticos}

Valendo-se da lição de Celso Antônio Bandeira de Mello, a professora Di Pietro (2011) entende que os agentes políticos estão ligados indissociavelmente às noções de governo e função política. Por isso, apenas podem ser considerados agentes políticos os membros do alto escalão do Poder Executivo e do Poder Legislativo, como o presidente da República, os governadores dos estados e do Distrito Federal, os prefeitos e seus respectivos auxiliares imediatos (ministros e secretários de diversas pastas), os senadores, deputados federais e estaduais, deputados do Distrito Federal e os vereadores.

Não há uniformidade de pensamento entre os doutrinadores na conceituação dos agentes políticos. Para Meirelles (2003, p. 75):

Os agentes políticos são os componentes do Governo nos seus primeiros escalões, investidos em cargos, funções, mandatos ou comissões, por nomeações, designações ou delegação para o exercício de atribuições constitucionais. Ele inclui nessa categoria tanto os Chefes do Poder Executivo federal, estadual, distrital e municipal, e seus auxiliares diretos, os membros do Poder Legislativo, tais como Senadores, Deputados Federais, Estaduais e Distrital, Vereadores, como também os membros dos Tribunais de Contas, da Magistratura, do Ministério Público, representantes diplomáticos e demais autoridades que atuem com independência funcional no desempenho das 
atribuições governamentais, judiciais, estranhas ao quadro do funcionalismo estatutário.

Mas o presente artigo não pretende revelar qual das posições doutrinárias tem razão. Pretendemos refletir como a Lei de Improbidade Administrativa se aplica aos agentes políticos.

Em 2007, o Plenário do Supremo Tribunal Federal proferiu decisão nos autos da Ação de Reclamação n 2138-6 e, por maioria absoluta (6 votos a 5), foi decidido que a Lei $n^{\circ}$ 8.429/92 (Lei de Improbidade Administrativa) não se aplicaria aos agentes políticos - presidente da República, ministros de Estado, senadores, deputados, governadores, prefeitos, vereadores, secretários etc. A eles se aplicaria regime jurídico próprio previsto na Constituição Federal (juízo exclusivo - v.g. impeachement).

Pazzaglini Filho, Rosa e Fazzio Júnior (1999) afirmam que o presidente da República, se autor de improbidade administrativa, não estaria sujeito às sanções de perda de função pública e suspensão dos direitos políticos, uma vez que estes estão submetidos a um regime jurídico constitucional próprio, previsto nos artigos 85 e 86 da Constituição Federal de 1988, ao disciplinar a cassação do chefe do Executivo e diante dos crimes de responsabilidade definidos pela Lei Federal $n{ }^{\circ} 1.079 / 50$.

Ainda nesse sentido, a perda do mandato presidencial somente se verifica por crime de responsabilidade enunciado na Constituição da República e especificado em lei especial (Lei n 1.079, de 10.04.1950). A competência para instaurar o processo é da Câmara dos Deputados, e para processá-lo e julgá-lo, é do Senado Federal, cabendo ao presidente do Supremo Tribunal Federal presidir o julgamento. Em eventual ação civil pública por ato de improbidade administrativa, o presidente da República responderia somente por sanções civis, descabendo sanções de perda da função e de suspensão dos direitos políticos (PAZZAGLINI FILHO, 2009).

Pazzaglini Filho (2009) acrescenta que os senadores e deputados federais ou estaduais somente estariam imunes à perda do cargo, e não 
às demais sanções, pois o art. 15, V, da Constituição Federal prevê a mesma sanção para os casos de improbidade administrativa.

A Lei $n^{\circ} 1.079$, de 10 de abril de 1950, definiu os crimes de responsabilidade do presidente da República e das demais autoridades federais e estaduais. Nesse diploma legal, há crimes contra a lei orçamentária, previstos no art. 10 do Capítulo VI, há crimes contra a probidade da administração, e mais oito novos delitos, com o mesmo conteúdo típico daqueles aditados ao art. $1^{\circ}$ do Decreto-Lei $n^{\circ}$ 201/67 (crimes de responsabilidade dos prefeitos).

Essas infrações penais, conforme preconizou Pazzaglini (2009), são verdadeiros crimes de responsabilidade (próprios), pois sua punição é exclusivamente de conteúdo político-administrativo, consistente na perda do cargo e inabilitação, por oito anos, para o exercício de qualquer função pública, tanto que sua aplicação não exclui a responsabilidade penal de seu autor por crime comum previsto no Código Penal (artigos 2 e 3 da Lei $\left.n^{\circ} 1.079 / 50\right)$.

Os crimes de prefeito estão previstos no art. $1^{\circ}$ do Decreto-Lei $n^{\circ}$ 201, de 27 de fevereiro de 1967, e vinculados ao exercício do mandato.

$\mathrm{O}$ art. $1^{\circ}$, parágrafo $2^{\circ}$, do diploma legal referido dispõe que a condenação definitiva em qualquer dos crimes definidos nesse artigo acarretará a perda do cargo e a inabilitação, pelo prazo de cinco anos, para o exercício de cargo ou função pública, eletivo ou de nomeação, sem prejuízo da reparação civil do dano causado ao patrimônio público ou particular.

A despeito do respeitado posicionamento mencionado, em nenhum momento a Constituição reservou à instância do julgamento político-administrativo o caráter de jurisdição exclusiva dos agentes políticos, na medida em que respondiam e respondem pelo fato também civil e criminalmente. (MARTINS, 2009). Preconiza Martins Júnior (2009, p. 311):

É bem verdade que o art. 85 da Constituição Federal sujeita o Presidente da República à responsabilidade político- 
administrativa, inclusive por improbidade administrativa (inciso V), regulada na Lei n. 1.079/50 aplicável a outros agentes políticos ali discriminados (Governadores de Estado, Ministros de Estado, Ministros do Supremo Tribunal Federal, Procurador Geral da República), com as sanções de perda do cargo e inabilitação para o exercício de qualquer função pública por prazo determinado, punições assemelhadas a algumas das previstas no art. 12 da Lei $n$. 8.429/92. A aplicação das penalidades da Lei n. 8.429/92 não é consumida pela aplicação das sanções políticoadministrativas, em razão da diversidade da natureza jurídica de cada uma delas e da própria extensão (prazos diferentes), sem que a extinção do mandato (renúncia, término, etc.) impeça a possibilidade da aplicação das demais sanções da Lei n. 8.429/92, sem a rejeição do processo político-administrativo.

Ainda defende o referido autor que a responsabilidade políticoadministrativa somente tem como sanções a perda do cargo e a inabilitação temporária para o exercício de qualquer função pública. As sanções decorrentes da Lei n 8.429/92 abrangem a perda de bens ou valores ilicitamente acrescidos, o ressarcimento dos danos ao erário público, a proibição de contratar com o poder público ou dele receber benefícios ou incentivos fiscais ou creditícios e o pagamento da multa civil, além da perda da função pública e a suspensão temporária dos direitos políticos - art. 37, parágrafo $4^{\circ}$, da Constituição Federal e art. 12 da Lei n 8.429/92. (MARTINS, 2009). Ele justifica sua assertiva:

O que há são instâncias diferentes e autônomas para diversas qualificações jurídicas de um mesmo fato. Embora o efeito prático de algumas sanções seja equivalente, não há reserva ou exclusividade de "jurisdição" ao Poder Legislativo para repressão da improbidade administrativa. O regime republicano é o da responsabilidade sem comportar a abertura de nichos de imunidade do poder, razão pela qual a Lei Federal n. 8.429/92 aplica-se a qualquer ato de improbidade administrativa de qualquer dos Poderes, abrangendo, pois, a improbidade em atos dos Poderes Executivo, Legislativo e Judiciário, sejam atos 
administrativos, legislativos ou jurisdicionais - art. $2^{\circ}$, Lei $\mathrm{n}$. 8.429/92. (MARTINS, 2009, p. 312)

Também nesse sentido, Marques (2010, p. 61):

Todo agente público que receber vantagem ilícita pode e deve ser investigado e processado nos âmbitos criminal, civil e administrativo. Excluir algumas autoridades apenas pelo fato de elas ocuparem cargos de alto escalão governamental infringe drasticamente o princípio da isonomia, previsto no ar. $5^{\circ}$, caput, da própria Constituição Federal. Não há qualquer fundamento razoável que exclua o Presidente da República e outras autoridades do espectro da Lei de Improbidade Administrativa.

Com razão, portanto, o Ministro Joaquim Barbosa, do Supremo Tribunal Federal, quando proferiu seu voto na Reclamação do STF $n^{\circ}$ 2.138:

[...] A meu sentir, a pretensa equiparação das condutas e sanções previstas na lei de improbidade a crimes de responsabilidade esvazia por completo o evidente caráter moralizador da Lei n. 8.429/92, restringindo seu alcance e aplicação. Afinal, a lei estabelece sanções aos agentes públicos nos casos de enriquecimento ilícito no exercício de mandato, cargo, emprego ou função na administração pública direta, indireta ou fundacional, sem prejuizo das sanções penais cabiveis. Em outros termos, o agente público passa a estar sujeito a outras espécies de sanções, de caráter não penal. E a averiguação das condutas contrária à lei de improbidade deve dar-se no ambiente próprio do amplo processo jurisdicional em primeira instância, não havendo que se falar em prerrogativa de foro nesses casos.

Discordamos de Motauri Ciocchetti de Souza (2000, p. 103), pois ele assevera que o membro do Ministério Público somente pode perder o cargo em caso de procedência da ação civil pública específica, proposta pelo Procurador Geral, conforme previsto na Lei Orgânica Nacional do Ministério Público (Lei n 8.625/93), que é posterior à Lei de Improbidade Administrativa. E os magistrados, segundo o mesmo autor, também não 
se sujeitam à referida sanção da Lei de Improbidade Administrativa, porque a Constituição Federal recepcionou a Lei Complementar $\mathrm{n}^{\circ}$ 35/79 (Lei Orgânica da Magistratura Nacional), a qual, em seu art. 26, arrolou as hipóteses exaustivas de perda do cargo.

Em que pese ser respeitável esse entendimento, não comungamos dessa tese, afinal, a Constituição Federal prescreve que o membro do Ministério Público e do Poder Judiciário obtém vitaliciedade após dois anos de exercício, não podendo perder o cargo senão por decisão judicial transitada em julgado. Não há, como se observa no referido texto constitucional, qualquer restrição à sentença proferida nos autos do processo da ação civil por ato de improbidade administrativa (art. 95, I e 128, parágrafo $5^{\circ}$, I, a) (MARQUES, 2010).

Conclui com acerto Marques (2010): em suma, os agentes políticos, independentemente da posição hierárquica ou do vínculo com o Poder Público, devem submeter-se às cominações por ato de improbidade administrativa.

Aliás, os agentes políticos representam 46,09\% dos réus que figuram no polo passivo das ações civis públicas por improbidade administrativa. Apenas $1,27 \%$ dos réus em ações civis públicas por ato de improbidade administrativa são magistrados e 0,09\% são promotores de justiça (SILVA; COSTA, 2011).

Acaso o STF entenda que a Lei de Improbidade Administrativa a eles não se aplica, somente os agentes públicos comuns sofrerão as penalidades previstas na Lei $n^{\circ} 8.429 / 92$. Alguns agentes políticos somente sofrerão as sanções da perda do cargo e a inabilitação temporária para o exercício de qualquer função pública se houver autorização e aplicação das sanções pelo Poder Legislativo (art. 52 da Constituição Federal). Se renunciarem ao cargo político ocupado, serão impunes aos atos de corrupção praticados. Além disso, estariam imunes do julgamento pelo Poder Judiciário. 


\section{Prerrogativa de foro}

$\mathrm{Na}$ ação civil por improbidade administrativa, não há competência originária para processar e julgar os réus que figuram no polo passivo da demanda.

Durante o governo do ex-presidente da República, Fernando Henrique Cardoso, por meio da Lei Federal $n^{\circ} 10.628 / 02$, foi acrescentado dois parágrafos ao art. 84 do Código de Processo Penal, estendendo a prerrogativa de foro às ações civis de improbidade administrativa (parágrafo $2^{\circ}$ ), mesmo que o inquérito ou a ação judicial sejam iniciados após a cessação do exercício da função pública (parágrafo $1^{\circ}$ ). Portanto, transferiu-se o julgamento para os tribunais que, originariamente, julgavam as ações criminais.

Na ocasião, muitas vozes se levantaram a favor do foro privilegiado, justificando que um juiz de primeira instância não poderia suspender os direitos políticos ou declarar a perda do cargo do presidente da República ou de um ministro de um tribunal superior, por exemplo. E o Supremo Tribunal Federal já havia revogado a Súmula 394, segundo a qual a prerrogativa funcional perdurava após a cessação daquele exercício, quando o crime fosse cometido durante ele (MARQUES, 2010).

Também foi argumentado nos tribunais brasileiros que lei ordinária não poderia ampliar as hipóteses de competência originária decorrentes da Constituição Federal.

Por isso, tanto a Associação dos Magistrados Brasileiros (AMB) quanto a Associação Nacional dos Membros do Ministério Público (CONAMP) ajuizaram ADIns no Supremo Tribunal Federal respectivamente, ADIn 2797 e ADIn 2860 - e o referido tribunal declarou, por maioria, a inconstitucionalidade dos parágrafos $1^{\circ}$ e $2^{\circ}$ do art. 84 do Código de Processo Penal.

Em apertada síntese, decidiu-se que a ação de improbidade administrativa não tem natureza penal, mas civil; e que a competência originária dos tribunais é, por definição, derrogação da competência 
ordinária dos juízos de primeiro grau, do que decorre que, demarcada a última pela Constituição, só ela pode executá-la. A relatoria dos processos foi do Ministro Sepúlveda Pertence, em 15 de maio de 2005.

Portanto, as ações por atos de improbidade administrativa devem ser ajuizadas em primeiro grau de jurisdição (juiz estadual ou federal, conforme o caso), não se aplicando a prerrogativa de foro prevista no texto constitucional.

\section{Sanção da perda da função pública}

Uma das sanções cominadas aos agentes ímprobos consiste na perda da função pública. Essa sanção poderá ser imposta em qualquer das hipóteses delineadas nos artigos $9^{\circ}, 10^{\circ}$ e $11^{\circ}$ da Lei no 9.429/92. No entanto, será executada somente após o trânsito em julgado da decisão prolatada na ação civil pública.

Mas o que se questiona é: a perda dessa função é aquela exercida quando da prática do ato ímprobo ou de qualquer outra função pública que o agente público exerça na época do trânsito em julgado da decisão judicial?

Exemplifiquemos: o contador de uma determinada prefeitura municipal comete um ato de improbidade administrativa e é condenado. Mas, durante a ação civil pública, ele mesmo pede exoneração do cargo e depois é recontratado para exercer outro cargo (comissionado no gabinete do prefeito ou aprovado em concurso público para diferente cargo público municipal, estadual ou federal). Portanto, questiona-se: a sanção da perda da função pública, nesse caso, perdeu o objeto na ação civil pública porque o réu da ação já se desligou da função pública que exercia, ou, quando do trânsito em julgado da r. sentença ou V. Acórdão, o servidor é atingido pelos efeitos da sentença e deve perder também a nova função pública? Preferimos a segunda assertiva. Conforme preconiza com acerto Marques (2010, p. 133):

A lei, em verdade, utilizou a expressão função pública em sentido amplo, significando o vínculo de qualquer 
pessoa física com órgão ou entidade pública, inclusive com as paraestatais. A sentença do magistrado ou tribunal competente, que nesse caso tem cunho constitutivo negativo, produz o rompimento do laço entre o agente ímprobo e o Estado. O coautor, partícipe, beneficiário ou herdeiro que não mantém vínculo com o órgão ou entidade pública obviamente não sofre essa penalidade, pois a lei á aplicável no que couber (art. $\left.3^{\circ}\right)$.

Também nesse sentido, Martins Júnior (2009, p. 364) assevera:

O agente público exibiu inidoneidade (ou inabilitação) moral e desvio ético para o exercício de função pública, expandindo-se para qualquer uma, mesmo se em nível de governo diferente da executada quando praticado $o$ ato ímprobo. De fato não há limitação: se o agente público era ímprobo quando exercia seu cargo efetivo na Administração Pública estatal, não foi a sentença que o constituiu na improbidade, mas a sua atuação, de forma que, se ao tempo do trânsito em julgado ele exerce cargo em comissão na Administração Pública federal ou outro cargo efetivo, a perda da função pública incidirá.

Carlos Alberto de Salles (2011, p. 90), no I Congresso do Patrimônio Público e Social realizado pelo Ministério Público do Estado de São Paulo através do Centro de Apoio Operacional Cível e de Tutela Coletiva, realizado entre os dias 18 e 21 de agosto de 2010, na cidade de São Paulo, tendo por tema jurídico "A efetividade da Lei de Improbidade Administrativa - 18 anos da Lei n 8.429/92", entende que essa sanção somente atinge a função pública exercida na época do ato ímprobo, asseverando que: "O texto legal em apreço não empresta respaldo para conclusão em contrário, pois não seria simples perda, como indicado no texto legal, mas verdadeira vedação de exercício de função que o agente não possuía quando da prática da improbidade".

Caso esse entendimento prevaleça, além dos fundamentos já expostos, a impunidade continuará prevalecendo, pois basta o servidor ímprobo sair do cargo antes ocupado para se prover em outro. A nosso ver, um incentivo à corrupção e à impunidade. 


\section{Transação nos atos de improbidade administrativa}

O artigo 17 , parágrafo $1^{\circ}$, da Lei $n^{\circ} 8.429 / 92$ veda expressamente acordo, transação ou conciliação nas ações civis públicas por ato de improbidade administrativa.

Essa proibição legal tem por fundamento a indisponibilidade do direito tutelado e a aplicação das demais sanções civis, administrativas e políticas cominadas para os atos de improbidade praticados.

Pazzaglini Filho (2009) vislumbra, como exceção à regra, uma única situação em que a transação, em caso de improbidade administrativa, poderia ser realizada: quando o autor da ação (Ministério Público ou pessoa jurídica lesada) tão somente postular, no caso de ato de improbidade administrativa que importa enriquecimento ilícito, a restituição integral do acréscimo patrimonial indevido e, na hipótese de ato de improbidade administrativa lesivo ao Erário, a reparação total da lesão patrimonial.

A questão é saber se seria cabível aos legitimados ativos da ação civil por ato de improbidade administrativa (Ministério Público ou pessoa jurídica interessada) transacionar com o ímprobo, com o intuito de aplicação imediata de alguma das sanções previstas no art. 12 da Lei $n^{\circ}$ 8.429/92, tornando-se a ação judicial desnecessária para tal finalidade.

Tem sido corriqueiro o Promotor de Justiça, no bojo de inquérito civil, fazer acordo com o agente público que causou prejuízo ao erário, garantindo o ressarcimento aos cofres públicos, de forma parcelada, mas, na sequência, arquiva o procedimento, sob o argumento de que não houve prova de improbidade administrativa, ou seja, de que o agente não agiu com dolo ou má-fé, o que justificaria o ajuizamento de ação civil pública por ato de improbidade administrativa.

É técnica e juridicamente um equívoco, pois, se não existe improbidade administrativa, qual a razão para instar o investigado a ressarcir o erário público? Defendemos, fundamentados no advento da Lei ${ }^{\circ}{ }^{\circ} 12.120$, de 15 de dezembro de 2009 , que possibilitou a 
aplicação das sanções de forma isolada ou cumulativa de acordo com a gravidade do fato, e com alicerce nos princípios da razoabilidade e proporcionalidade, ser imprescindível a mitigação da vedação à transação na repressão aos atos de improbidade administrativa.

Objetiva-se, com isso, permitir a aplicação consensual de algumas sanções aos agentes ímprobos de forma imediata e rápida, sem batalhas judiciais de longa data.

No I Congresso do Patrimônio Público e Social realizado pelo Ministério Público do Estado de São Paulo através do Centro de Apoio Operacional Cível e de Tutela Coletiva, Adriana Ribeiro Soares de Morais (2011, p. 210), preconizou:

Com efeito, o membro do Ministério Público realiza juízo de valor de razoabilidade e proporcionalidade de sanção, apenas de aplicação de multa civil e/ou proibição de contratar com o poder público ou receber benefícios fiscais ou creditícios, considerando, inclusive, o gasto econômico deste processo, o qual poderá arrastar-se por anos, com interposição de recursos extraordinários, inclusive.

Adriana de Morais (2011, p. 210) ainda asseverou com bastante propriedade:

No âmbito cível por que não aceitar a improbidade administrativa de menor potencial ofensivo? Neste caso, por que não permitir ao promotor de justiça a celebração de uma transação com o ímprobo, com o fim de, sem a propositura de ação civil, reconhecer o cometimento de ato de improbidade administrativa e concordar com o ressarcimento integral ao erário/perdimento dos bens ou valores, além de aplicação de uma ou mais sanções, dependendo da situação concreta a ser analisada pelo promotor de justiça, tendo como critério norteador as reiteradas decisões dos Tribunais Superiores, lastreadas nos princípios da razoabilidade e proporcionalidade das sanções? 
Não se desconhece que um recente acórdão do Superior Tribunal de Justiça, de relatoria do Ministro Herman Benjamin, afastou por completo a aplicação do princípio da insignificância, a fim de reconhecer o ato de improbidade administrativa na seguinte situação: "Chefe de Gabinete do Município que utilizou veículo de propriedade municipal e força de trabalho de três membros da Guarda Municipal para transportar utensílios e bens particulares" (Resp n 892.818 - RS - Rel. Ministro Herman Benjamin, DJ: 10.02.10).

Destarte, exemplificamos nosso entendimento: o agente público adultera nota fiscal no processo de prestação de contas em regime de adiantamento, ou o agente público contrata funcionário fantasma para receber dois salários, ou mesmo, em outro caso, num processo licitatório, não se respeita o prazo de publicidade previsto na lei de licitação (Lei n - 8.666/93). Todos os exemplos demandariam ações civis públicas por improbidade administrativa, que tramitariam por vários anos, para se obter, após comprovado o dano ao erário e a má-fé e desonestidade do servidor ímprobo, o ressarcimento aos cofres públicos, a proibição de contratar com o poder público e de receber dele benefícios fiscais, além da perda do cargo e suspensão dos direitos políticos.

Nos casos supramencionados, poderia o promotor de justiça, adequando-se aos princípios da proporcionalidade e razoabilidade, transacionar com o agente ímprobo? Este reconhece sua má-fé e desonestidade, ressarce integralmente os cofres públicos e admite a aplicação de uma das sanções (perda do cargo, suspensão dos direitos políticos, multa civil ou proibição de contratar com o poder público), livrando-se das demais cominações.

Esse ato de transação deve ser regulamentado em legislação própria, prevendo-o sob o crivo de homologação no Conselho Superior do Ministério Público. E mais, a alteração legislativa há de regular o valor em dinheiro permitido para se transacionar.

Por isso, é necessário que se encaminhe uma proposta de alteração legislativa à Lei de Improbidade Administrativa, visando à 
mitigação da vedação à transação, acordo ou conciliação nas ações de improbidade administrativa.

A resposta da atuação estatal à sociedade, com a devolução ao erário público, é imediata, aplicando-se uma das sanções previstas.

O Grupo Jurídico da Estratégia Nacional de Combate à Corrupção e Lavagem de Dinheiro (ENCCLA), do Ministério da Justiça, firmou entendimento acerca da viabilidade de aplicação consensual de sanção no âmbito cível da improbidade, assegurando sempre o ressarcimento integral do dano e a aplicação de, pelo menos, uma das sanções previstas no art. 12 da Lei ${ }^{\circ} 8.429 / 92$.

\section{Eficácia da lei de improbidade administrativa}

O Ministério Público vem exercendo, ao longo dessas duas últimas décadas, papel da maior relevância no contexto nacional, na defesa do patrimônio público e social. O relatório do Cadastro Nacional de Condenações Cíveis por Ato de Improbidade Administrativa, publicado em 17 de janeiro de 2011 pelo Conselho Nacional de Justiça, revelou que foram cadastradas pelos Tribunais de Justiça Estaduais e Tribunais Regionais Federais 3.393 condenações dessa natureza, todas com trânsito em julgado. Desse total, 1.301 (aproximadamente 38\%) oriundas do Tribunal de Justiça do Estado de São Paulo (SÃO PAULO, 2011).

Dados colhidos no SIS-MP Integrado do Ministério Público do Estado de São Paulo revelam que somente no ano de 2010, na área específica de defesa do patrimônio público e social, foram instaurados 600 procedimentos preparatórios de inquérito civil e 4.327 inquéritos civis. Demonstram, ainda, que foram propostas 897 ação civis públicas por improbidade administrativa, com valores das causas totalizando mais de R\$ 2,5 bilhões. No período de 1992 a 2009, o total de valores questionados para devolução ou ressarcimento aos cofres públicos do estado de São Paulo e do município de São Paulo, em ações civis públicas definitivamente julgadas procedentes e em fase de execução, supera os $\mathrm{R} \$ 138$ milhões. Se consideradas aquelas julgadas procedentes em $1^{\circ}$ 
grau, ainda pendentes de julgamento de recursos, o total ultrapassa $R \$$ 8 bilhões, em valores nominais, não atualizados (SÃO PAULO, 2011).

No site do Ministério Público de São Paulo, diariamente, podem ser consultadas as ações contra agentes ímprobos (obtenção de liminar de indisponibilidade de bens de agentes públicos réus em ações por improbidade, suspensão dos direitos políticos, afastamento cautelar de agentes, condenações de prefeitos, vereadores, secretários, etc. por ato de improbidade administrativa).

O volume de ações ainda é diminuto frente aos desmandos de corrupção de que temos notícias pela imprensa, e menores ainda são as condenações que se perdem no tempo e na memória nos Tribunais Superiores (STJ e STF), proporcionando uma verdadeira impunidade.

Há discrepância exagerada entre uma região e outra do estado no tocante ao número de ações por improbidade administrativa. Enquanto no Tribunal de Justiça de São Paulo e de Minas Gerais existem 8.152 e 3.436 ações civis públicas por improbidade administrativa, respectivamente, no Tribunal de Justiça do Pará e na Bahia, há somente 63 e 75, respectivamente. De todo o acervo de ações civis públicas existentes nos Tribunais de Justiça do Brasil, 89\% são propostas pelos Ministérios Públicos Estaduais e Ministério Público Federal. As demais, pelas entidades lesadas (União, estados, Distrito Federal e municípios) (SILVA; COSTA, 2011).

De todas as absolvições de ações civis públicas propostas pelo Ministério Público, 18,59\% são por falta de provas quanto ao efetivo dano ao erário público.

A experiência processual revela que essa comprovação quanto ao efetivo dando ao erário público é tormentosa, afinal, os próprios agentes públicos conluiados atestam falsamente recebimento de mercadorias e materiais, bem como de execução de serviços públicos e medição de obras.

Por isso, é necessária a mudança legislativa, visando à inversão do ônus da prova, devendo o próprio agente público réu no processo comprovar que não causou dano ao patrimônio público. Se ele pratica 
ato administrativo com má-fé e desonestidade e ofende os princípios da administração pública de forma dolosa e fraudulenta (art. 11 da Lei $n^{\circ}$ 8.429/92), deverá provar que não causou dano ao erário público. Nesse sentido:

AÇÃO CIVIL PÚBLICA - Ausência de licitação - Inteligência do Art. 24 da Lei $n^{\circ} 8.666 / 93$ - Indevido fracionamento de serviço contínuo - Ofensa aos princípios da moralidade, legalidade, impessoalidade e publicidade - Afastamento da condenação de devolução dos valores pagos, vez que o serviço foi efetivamente prestado e não há demonstração de superfaturamento - Recursos parcialmente providos. (Rel. Aliende Ribeiro. Julg. 6 fev. 2012. Reg. 10 fev. 2012).

Um ponto positivo a ser realçado: de todas as ações civis públicas propostas pelos Ministérios Públicos (Estadual e Federal), 63,82\% são julgadas procedentes ou parcialmente procedentes, revelando, ao contrário do que pensávamos, que as demandas do sistema judicial de combate à improbidade administrativa (corrupção) ficam acima do esperado. Esses dados permitem afastar a premissa de que a Lei de Improbidade Administrativa não é efetiva - pelo menos no que tange à demanda de conhecimento condenatória (SILVA; COSTA, 2011).

O problema é na fase executória. Depois de anos e anos, o agente público já não mais está exercendo o cargo que exercia quando da prática da improbidade e dissipou todos os seus bens possíveis de ressarcir ao erário, restando apenas a suspensão dos direitos políticos e a proibição de contratar com o poder público. Mais um motivo para sairmos em defesa da mitigação à proibição de transação, acordo ou composição nas ações civis por ato de improbidade administrativa.

\section{Conclusão}

O regime jurídico da Lei de Improbidade Administrativa é de ordem constitucional. E o referido diploma legal reprime a corrupção que fere de morte a democracia. Conforme preconiza Sabella (2008, p. 29): 
Instalando-se como canal de evasão de recursos do erário, a corrupção atua como barreira impeditiva das atividades prestacionais do Estado, pois insólito seria admitir alguma espécie de serviço público cuja execução prescindisse de recursos. E dela decorrendo esse efeito perverso, resulta inevitável a afirmação de que à corrupção se associa a grave violação a um direito fundamental, ou seja, o direito à boa administração pública.

A Lei Federal $n^{\circ} 8.429 / 92$ é, na verdade, uma Lei Geral de Improbidade Administrativa (LGIA) e um Código Geral de Conduta, com normativa jurídica, cogente e balizador de todo o setor público em suas vertentes fundamentais.

Os atos de improbidade administrativa descritos no diploma legal supramencionado não devem ser banalizados de forma que apenas um descumprimento da letra fria da lei ou do ordenamento possa ser considerado ato ímprobo. A comprovação da maldade, máfé, desonestidade e fraude são premissas essenciais, além da própria ilegalidade.

Os Tribunais Superiores (STJ e STF) devem seguir entendimento firme e uniforme para aplicar a Lei de Improbidade Administrativa também aos agentes políticos, pois, a nosso ver, o diploma legal foi criado exatamente para eles, pois detêm o poder e a competência para executar o gasto do dinheiro público. E, como visto, são eles os que mais aparecem no polo passivo das ações de improbidade administrativa que tramitam atualmente no Poder Judiciário brasileiro.

Já dizia Maquiavel (2011) que o povo tem objetivos mais honestos do que a nobreza; esta quer oprimir, enquanto o povo deseja apenas evitar a opressão. É de suma importância controlar e punir com severidade aqueles que ocupam o alto escalão do Estado.

O Estado precisa dar à sociedade uma resposta mais rápida e uma punição mais imediata frente à prática diária dos atos de corrupção. Para tanto, acreditamos que a mitigação à vedação, transação ou composição dos atos ímprobos deve acelerar a resposta estatal. 
O agente, numa forma de transação com o Ministério Público ou órgão público lesado, reconhece sua má-fé, concorda em ressarcir integralmente o erário público e, com a imposição de mais uma sanção prevista, fica livre das demais. Isso evita batalhas judiciais de longa data, as quais estão levando o Estado ao descrédito, em razão da morosidade nos julgamentos dos agentes corruptos e ímprobos.

É lógico que a alteração da legislação disciplinará as hipóteses de transação e aplicação imediata das sanções estipulando o limite do valor desviado ou fraudado, mas sempre mediante a devolução integral do dinheiro público.

Como apontado, portanto, algumas alterações legislativas da Lei de Improbidade Administrativa são imprescindíveis para a maior efetividade do diploma legal em comento (inversão do ônus da prova quanto à comprovação do dano ao erário público, previsão expressa de que a perda da função pública deve consistir no desligamento total do servidor ímprobo com a administração pública e mitigar a vedação ou proibição de transação e composição nos atos de improbidade administrativa).

O Brasil evoluiu muito no combate à corrupção. Nunca se processou e condenou tantos agentes públicos corruptos, políticos e particulares que praticaram atos de improbidade administrativa.

Ainda é pouco frente ao crescente número de atos de corrupção veiculado na imprensa diariamente. Muito ainda há ser feito e realizado no combate à improbidade administrativa. Estamos num processo de transformação e amadurecimento.

\section{Referências}

BRASIL. Decreto-lei n. 201, de 27 de fevereiro de 1967. Dispõe sobre a responsabilidade dos Prefeitos e Vereadores, e dá outras providências. Diário Oficial da União, Poder Executivo, Brasília, DF, 27 fev. 1967. p. 2348. Disponível em: <http://www.planalto.gov.br/ccivil_03/decreto-lei/ de10201.htm>. Acesso em: 12 set. 2012. 
BRASIL. Lei n. 8429/92, de 2 de junho de 1992. Dispõe sobre as sanções aplicáveis aos agentes públicos nos casos de enriquecimento ilícito no exercício de mandato, cargo, emprego ou função na administração pública direta, indireta ou fundacional e dá outras providências. Diário Oficial da União, Poder Executivo, Brasília, DF, 3 jun. 1992. Disponível em: <http://planalto.gov.br/ccvil_03/leis//8429.htm>. Acesso em: 12 set. 2012.

BRASIL. Lei n. 1.079, de 10-04-1950. Define os crimes de responsabilidade e regula o respectivo processo de julgamento. Diário Oficial da União, Poder Executivo, Brasília, DF, 3 jun. 1992. Disponível em: <http://planalto.gov.br/ccvil_03/leis/l1079.htm>. Acesso em: 12 out. 2012.

BRASIL. Superior Tribunal de Justiça. Jurisprudência. Disponível em: <http://www.stj.gov.br/portal_stj/publicação/engine.wsp>. Acesso em: 15 jan. 2012.

CAETANO, Marcello. Manual de direito administrativo. Rio de Janeiro: Forense, 1970.

DI PIETRO, Maria Sylvia Zanella. Direito administrativo. 24. ed. São Paulo: Atlas, 2011.

FIGUEIREDO, Marcelo. Probidade administrativa: comentários à lei n 8.429/92 e legislação complementar. São Paulo: Malheiros, 2004.

GARCÍA DE ENTERRÍA, Eduardo. Curso de derecho administrativo II. 5. ed. Madri: Civitas, 1998.

MAQUIAVEL. O Príncipe. Comentado por Napoleão Bonaparte. 10. ed. São Paulo: Martin Claret, 2011.

MARQUES, Sílvio Antônio. Improbidade administrativa. São Paulo: Saraiva, 2010.

MARTINS JÚNIOR, Wallace Paiva. Probidade administrativa. 4. ed. São Paulo: Saraiva, 2009.

MEIRELLES, Hely Lopes. Direito administrativo brasileiro. 29. ed. São Paulo: Malheiros, 2004. 
MELLO, Celso Antônio Bandeira de. Curso de direito administrativo. 27. ed. São Paulo: Malheiros, 2010.

MORAES, Alexandre de. Direito constitucional. 26. ed. São Paulo: Atlas, 2011.

OSÓRIO, Fábio Medina. Teoria da improbidade administrativa. São Paulo: Revista dos Tribunais, 2007.

PAZZAGLINI FILHO, Marino. Lei de Improbidade Administrativa comentada. 4. ed. São Paulo: Atlas, 2009.

PAZZAGLINI FILHO, Marino; ROSA, Márcio Fernando Elias; FAZZIO JUNIOR, Waldo. Improbidade administrativa: aspectos jurídicos da defesa do patrimônio público. 4. ed. São Paulo: Atlas, 1999.

PLATÃO. República. Bauru: Edipro, 1994.

PRADO, Francisco Octávio de Almeida. Improbidade administrativa. São Paulo: Malheiros, 2001.

SÃO PAULO. Ministério Público do Estado de São Paulo. Centro de Apoio Operacional Cível e de Tutela Coletiva. Manual prático de atuação das Promotorias de Justiça de Patrimônio Público. São Paulo: Imprensa Oficial, 2011.

SABELLA, Valter Paulo. Ministério Público, combate à corrupção e contre das políticas públicas. Revista APMP: Associação Paulista do Ministério Público, São Paulo, v. 13, n. 48, p. 28-31, set./dez. 2008.

SILVA, Paulo Eduardo Alves da; COSTA, Susana Henrique da. Improbidade administrativa: a eficácia do sistema jurídico de prevenção e combate à improbidade administrativa. São Paulo: FDUSP, 2011. (Pensando o direito, n. 34).

Data de recebimento: $14 / 03 / 13$

Data de aprovação: 04/12/13 